NBER WORKING PAPER SERIES

\title{
FINANCIAL OPENNESS, SUDDEN STOPS AND CURRENT ACCOUNT REVERSALS
}

\author{
Sebastian Edwards \\ Working Paper 10277 \\ http://www.nber.org/papers/w10277 \\ NATIONAL BUREAU OF ECONOMIC RESEARCH \\ 1050 Massachusetts Avenue \\ Cambridge, MA 02138 \\ January 2004
}

This paper has been prepared for presentation at the American Economic Association Annual Meetings, San Diego, January 3-5, 2004. The views expressed herein are those of the authors and not necessarily those of the National Bureau of Economic Research.

(C)2004 by Sebastian Edwards. All rights reserved. Short sections of text, not to exceed two paragraphs, may be quoted without explicit permission provided that full credit, including (C) notice, is given to the source. 
Financial Openness, Sudden Stops and Current Account Reversals

Sebastian Edwards

NBER Working Paper No. 10277

January 2004

JEL No. F30, F32

\begin{abstract}
In this paper I use a panel data set to investigate the mechanics of sudden stops of capital inflows and current account reversals. I am particularly interested in four questions: (a) What is the relationship between sudden stops and current account reversals? (b) To what extent does financial openness affect the probability of a country being subject to a current account reversal? In other words, do restrictions on capital mobility reduce the probability of such occurrences? (C) Does openness - both trade openness and financial openness - play a role in determining the effect of current account reversals on economic performance (i.e. GDP growth)? And, (d) does the exchange rate regime affect the intensity with which reversals affect real activity? The empirical analysis shows that sudden stops and current account reversals have been closely related. The econometric analysis suggests that restricting capital mobility does not reduce the probability of experiencing a reversal. Current account reversals, in turn, have had a negative effect on real growth that goes beyond their direct effect on investment. The regression analysis indicates that the negative effects of current account reversals on growth will depend on the country's degree of trade openness: More open countries will suffer less - in terms of lower growth relative to trend - than countries with a lower degree of trade openness. On the other hand, the degree of financial openness does not appear to be related to the intensity with which reversals affect real economic performance. The empirical analysis also suggests that countries with more flexible exchange rate regimes are able to accommodate better shocks stemming from a reversal than countries with more rigid exchange rate regimes.
\end{abstract}

Sebastian Edwards

UCLA Anderson Graduate School of Business

110 Westwood Plaza, Suite C508

Box 951481

Los Angeles, CA 90095-1481

and NBER

sedwards@anderson.ucla.edu 


\section{FINANCIAL OPENNESS, SUDDEN STOPS}

AND CURRENT ACCOUNT REVERSALS

\section{by \\ Sebastian Edwards*}

Since the currency crises of the 1990s economists have had a renewed interest in understanding the behavior of international capital flows. A number of authors have argued that in a world of high capital mobility "sudden stops" of capital inflows can be highly disruptive. According to these authors, sudden stops tend to result in major current account reversals, and in costly adjustment processes (Rudi Dornbusch, Ilan Goldfajn and Rodrigo Valdés 1995). There are two important policy issues regarding sudden stops and current account reversals: First, what determines the occurrence of these phenomena? And second, what are the effects of sudden stops, and current account reversals, on countries' economic performance. In this paper I use a panel data set to investigate the mechanics of sudden stops and reversals. I am particularly interested in four questions: (a) What is the relationship between sudden stops and current account reversals? (b) To what extent does financial openness affect the probability of a country being subject to a current account reversal? In other words, do restrictions on capital mobility reduce the probability of such occurrences? (C) Does openness - both trade openness and financial openness - play a role in determining the effect of current account reversals on economic performance (i.e. GDP growth)? And, (d) does the exchange rate regime affect the intensity with which reversals affect real activity?

\section{Sudden Stops and Current Account Reversals}

I define a current account reversal as a reduction in the current account deficit of at least $4 \%$ of GDP in one year. A sudden stop, on the other hand, is defined as an abrupt 
and major reduction in capital inflows to a country that has been receiving large volumes of foreign capital. In particular, a sudden stop occurs when net capital inflows have declined by at least 5\% of GDP in one year (see Edwards 2004 for details).

Using a panel data set for 157 countries I found that during 1970-2001 there was a $5.6 \%$ incidence of sudden stops; the incidence of reversals was $11.8 \%$. Not surprisingly, these two phenomena have been closely related. However, the relationship is less than perfect. Historically there have been many sudden stops that have not been related to reversal episodes. This indicates that when facing a sudden stop, many countries have effectively used their international reserves to avoid an abrupt current account adjustment. At the same time, a number of countries have gone through major current account reversals without facing a sudden stop in inflows. Most countries in this group were not receiving large inflows to begin with, and had financed their large deficits by drawing down international reserves (see Edwards, 2004).

For the complete sample (2,228 observations), $46.1 \%$ of countries subject to a sudden stop faced a current account reversal. At the same time, $22.9 \%$ of those with reversals also experienced (in the same year) a sudden stop. The joint incidence of reversals and sudden stops has been highest in Africa, where approximately $62 \%$ of sudden stops happened at the same time as current account reversals, and almost $30 \%$ of reversals coincided with sudden stops. For every one of the regions, as well as for the complete sample, Pearson $\chi^{2}$ tests for the independence of distributions have very small p-values, indicating that although there are observed differences between these two phenomena, the two are statistically related. For the complete sample the $\chi^{2}$ statistic for the null hypothesis of independence of distributions has a value of 159.8. These results 
do not change in any significant way if different definitions of reversals and sudden stops are used, or if different configurations of lags and leads are considered.

\section{Openness and the Costs of Current Account Reversals}

I use the data set described above to investigate two issues: (a) Does the probability of experiencing a current account reversal depend on the country's degree of financial openness? And (b), do the effects of current account reversals on real economic activity (GDP growth) depend on the country's degree of trade and financial openness? ${ }^{1}$

Some authors have argued that "excessive" capital mobility is highly disruptive. According to them, restricting the degree of capital mobility will reduce the probability that a country faces an external crisis, including a sudden stop and a current account reversal (Joseph Stiglitz 2002). Whether this is indeed the case is, of course, an empirical issue. The results reported in this paper, then, shed some light on this policy question, as they provide a historical assessment of the effectiveness of capital controls.

In a number of models the costs of foreign shocks - including sudden stops and current account reversals -- are inversely proportional to the country's degree of openness. In Mundell-Fleming type of models the expenditure reducing effort, for any given level of expenditure switching, is inversely proportional to the marginal propensity to import. In these models adjustment costs are also inversely proportional to the degree of financial integration. Countries with a higher degree of financial openness will require a smaller reduction in aggregate income to accommodate external shocks than countries with a lower degree of financial integration (Jacob Frenkel and Assaf Razin 1987).

Recently, Guillermo Calvo, Alejandro Izquierdo and Luis Mejia (2003) developed a model where sudden stops result in abrupt current account reversals, and in major real 
exchange rate depreciations. Depreciations, in turn, are contractionary, with the extent of the contraction depending inversely on the degree of trade openness of the economy. They argue that sudden stops and current account reversals will have a greater impact in closed economies - such as Argentina - than in more open ones, such as Chile.

Previous empirical works on the effects of current account reversals on real economic performance have reached different conclusions. Gian Maria Milesi-Ferreti and Razin (2000), for example, concluded that "reversal... are not systematically associated with a growth slowdown (p. 303)." Edwards (2002), on the other hand, used dynamic panel regressions and concluded that major current account reversals had a negative effect on investment, and on GDP per capita growth, even after controlling for investment. Neither of these papers, however, analyzed the interaction between openness or the exchange rate regime, and the costs of current account reversals.

\section{A. The Empirical Model}

I use a "treatment effects" model to estimate jointly an equation on real GDP growth and a probit equation on the probability of a current account reversal.

$$
\mathrm{g}^{*}{ }_{\mathrm{j}}=\phi+\mathbf{x}_{\mathbf{j}} \beta+\omega_{\mathrm{j}}
$$

$$
\Delta g_{t j}=\lambda\left[g^{*}{ }_{j}-g_{t-1}\right]+\varphi v_{t j}+\gamma \delta_{t j}+\theta\left(\delta_{t j} \text { Openness }_{t j}\right)+\xi_{t j} .
$$

$$
\delta_{\mathrm{tj}}= \begin{cases}1, & \text { if } \delta *_{\mathrm{tj}}>0 \\ 0, & \text { otherwise }\end{cases}
$$

$$
\delta *_{t j}=\mathbf{w}_{\mathbf{t} \mathbf{j}} \alpha+\varepsilon_{\mathrm{tj}}
$$


Equation (1) is a long run growth equation. $\mathrm{g}^{*}{ }_{\mathrm{j}}$ is long run real per capita GDP growth in country $\mathbf{j} ; \mathbf{x}_{\mathbf{j}}$ is a vector of covariates that capture the role of traditional determinants of growth, and $\omega_{\mathrm{j}}$ is an error term. Equation (2) is a growth dynamics equation, where [ $\mathrm{g}^{*} \mathrm{j}$ $-\mathrm{g}_{\mathrm{t}-1 \mathrm{j}}$ ] is a partial adjustment term (the "growth gap"), $\mathrm{v}_{\mathrm{tj}}$ is a terms of trade shock, and $\delta_{\mathrm{tj}}$ is a dummy variable (i.e. the treatment variable) that takes a value of one if country $\mathrm{j}$ in period $\mathrm{t}$ experienced a current account reversal, and zero if the country did not experience a reversal. Thus, $\gamma$ is the parameter of interest: the effect of the treatment on the outcome. Finally, $\left(\delta_{\mathrm{tj}}\right.$ Openness $\left._{\mathrm{tj}}\right)$ is a variable that interacts $\delta_{\mathrm{tj}}$ with a measure of openness. Whether the country experiences a current account reversal is assumed to be the result of an unobserved latent variable $\delta^{*}{ }_{\mathrm{j}}$, in equation (3). $\delta^{*} \mathrm{j}$, in turn, is assumed to depend on vector $\mathbf{w}_{\mathbf{j}}$. Some of the variables in $\mathbf{w}_{\mathbf{j}}$ may be included in $\mathbf{x}_{\mathbf{j}}$.

Exclusionary restrictions are imposed for identification purposes. $\beta$ and $\alpha$ are parameter vectors. $\xi_{\mathrm{jt}}$ and $\varepsilon_{\mathrm{jt}}$ are error terms assumed to be bivariate normal, with a zero mean and a covariance matrix:

$$
\left(\begin{array}{ll}
\sigma & \varsigma \\
\varsigma & 1
\end{array}\right)
$$

A two-step estimation procedure is used. Equation (1) is estimated using data for long-term averages and Feasible Least Squares. Fitted values of long term growth are used as $g *_{j}$ in equation (2). Equations (2) and (4) are then estimated jointly. In the estimation of equation (2), I included terms that interact the dummy variable $\delta_{\mathrm{tk}}$ with two openness variables - one for trade and one for financial openness. Trade openness is defined as the ratio of imports plus exports to GDP. Financial openness is measured 
using a new index based on Dennis Quinn's (2003) index of capital mobility. This index goes from 1 to 100, with higher values denoting a higher degree of financial integration. Thus, countries with stricter capital controls have a lower value of this index. Since I am interested in understanding the role of financial openness in the probability of reversals, one of the $\mathbf{w}_{\mathbf{j}}$ in equation (4) is the index of financial integration described above.

In the long run growth equation (1) the dependent variable is real GDP growth per capita. The following covariates were included: the log of initial GDP per capita; the investment ratio; the coverage of secondary education; an index of the degree of openness of the economy; the ratio of government consumption to GDP; and regional dummies. In some specifications I also included an indexes for the exchange rate regime. Results from the estimation of (1) are not reported due to space constraints.

In the growth equation (2) $\mathrm{v}_{\mathrm{tj}}$ is the change in the terms of trade, and $\delta_{\mathrm{tj}}$ is the current account reversals dummy. As stated, I also included the current account reversal dummy interacted with the trade openness variable, and interacted with the financial openness index. If reversals have a negative impact on (short-term) growth, the coefficient of the reversals' dummy will be significantly negative. If this effect is inversely proportional to the country's degree of openness, the coefficients of the interaction between reversals and openness should be significantly positive.

In specifying equation (4) I followed the empirical literature on crises, and I included the following covariates (all lagged one period): (a) The ratio of the current account deficit to GDP. (b) The external debt to GDP. (c) Net international reserves to GDP. (d) The share of short term external debt. (e) The relative occurrence of sudden stops in the country's region. (f) Growth of domestic credit. (h) The log of initial per 
capita GDP. (g) An index of financial integration. And (i) country-specific dummies.

\section{B. Results}

In Table 1 I summarize the basic results obtained from the estimation of a number of treatment models for GDP growth dynamics (the coefficients of the country specific dummies are not reported). The table contains two panels. The upper panel (A) includes the results from the growth equation; the lower panel (B) contains the estimates for the "treatment equation," or probit equation on the probability of experiencing a current account reversal. As pointed out above, the treatment observations correspond to current account reversal episodes. Table 1 also includes the estimated coefficient of the hazard lambda, as well as the estimated elements of the variance-covariance matrix (5). The first three equations are for emerging markets. The last equation (1.4) is for the complete sample of emerging and industrial countries. I discuss first the results from the probit equations on the probability of reversals. I then focus on the results from the dynamics of growth equations.

The probit estimates are presented in the lower panel of Table 1. The results are similar across models, most coefficients have the expected signs, and are statistically significant at conventional levels. These results indicate that the probability of experiencing a reversal is higher for countries with a large (lagged) current account deficit, a high external debt ratio, a rapid rate of growth of domestic credit, lower initial GDP, and a high occurrence of sudden stops in their region. Countries that have a higher level of net international reserves have a lower probability of experiencing a reversal. The coefficients of the short-term debt have the expected sign, but tend not to be significant. Particularly important for the subject of this paper, the coefficient of the 
financial openness index is negative in all regressions, and it is and significantly negative in equation (1.4) for the complete sample. This provides some (weak) evidence suggesting that countries with a higher degree of financial openness have a lower probability of facing a current account reversal. That is, contrary to what has been argued by critics of globalization, these results suggest that the presence of capital account restrictions does not reduce the probability of an external crisis. These results are robust to the sample used, as well as to the specification of the probit equation. A possible explanation is that the public finds way to circumvent the restrictions. In addition, it is possible that in countries with capital controls the authorities become overconfident, and tend to implement more "risky" macroeconomic policies.

The results from the estimation of the growth dynamics equation are reported in Panel A. The growth gap and the terms of trade coefficients have the expected signs and are significant. More importantly, the coefficients of the current account reversal dummy is always significantly negative, and the coefficients of the term that interacts trade openness and reversals is always significantly positive. Thus, the effects of a current account reversal on growth depend significantly on the degree of trade openness of the economy. This result can be illustrated for the case of equation (1.1):

Growth Effects of Reversals $=-6.025+0.032$ trade openness.

The variable "trade openness" varies significantly across countries. Its mean is $65 \%$, its standard deviation is $35 \%$, and its median is $67.4 \%$. The first decile is $28.7 \%$, and the ninth decile is $130.7 \%$. For a country with a degree of openness equal to the mean, the 
point estimate of the effect of a reversal on GDP growth (relative to trend) is: $-3.945 \%$ ($6.025+0.032 \times 65=-3.945$ ). If the country's degree of openness is low and equal to the first decile, the effect of a reversal on growth is more negative and equal to $-5.11 \%$. But if the country is very open to trade, and its degree of openness corresponds to the ninth decile, the effect of a reversal on growth is much smaller, at $-1.84 \%$.

In equations (1.2) and (1.3) the estimated coefficient of the variable that interacts reversals and financial openness is negative but not significant. All in all, these results suggest that of financial openness has no effect on the way in which reversals affect growth. This contrasts with the results in equations (1.1) and (1.4) that indicate that trade openness mitigates the effects of reversals on economic growth.

\section{Current Account Reversals and Exchange Rate Regimes}

An important question is whether the effects of reversals on growth (relative to trend) depend on the exchange rate regime. To address this issue I divided the sample according to four alternative de-facto regimes: hard peg; pegged, intermediate and flexible (see Edwards and Eduardo Levy-Yeayati, 2003 for the classification). I then compared the estimates of both the reversals treatment dummy, as well as the term that interacts reversals and trade openness. The results may be summarized as follows: the estimated coefficient of reversals (z-statistic) for pegged regimes was -6.573 (-4.43). For flexible rates it was positive and not signiticant: 0.373 (1.09). The interactive term was 0.041 (3.43) for pegged and -0.044 (-1.01) for flexible regimes. A $\chi^{2}$ test indicates that these differences in coefficients across regimes are significant. All in all, these results support the idea that flexible exchange rates act as shock absorbers, allowing countries to accommodate better external shocks, including current account reversals. 


\section{Concluding Remarks}

In this paper I have shown that sudden stops and current account reversals have been closely related. The econometric analysis suggests that restricting capital mobility does not reduce the probability of experiencing a reversal. Current account reversals, in turn, have had a negative effect on real growth that goes beyond their direct effect on investment. The regression analysis indicates that the negative effects of current account reversals on growth will depend on the country's degree of trade openness: More open countries will suffer less - in terms of lower growth relative to trend- than countries with a lower degree of trade openness. On the other hand, the degree of financial openness does not appear to be related to the intensity with which reversals affect real economic performance. The empirical analysis also suggests that countries with more flexible exchange rate regimes are able to accommodate better shocks stemming from a reversal than countries with more rigid exchange rate regimes. In interpreting the findings reported in this paper, it is important to keep in mind that measuring financial integration is far from easy (Quinn 2003). Further work on the subject should aim at producing even better indexes of financial integration and capital account restrictions. 


\section{$\underline{\text { References }}$}

Calvo, Guillermo, Izquierdo, Alejandro and Luis Mejia (2003): “On the Empirics of Sudden Stops,” Working Paper, Interamerican Development Bank.

Dornbusch, Rudinger, Goldfajn, Ilan and Valdes, Rodrigo O. (1995): “Currency Crises and Collapses", Brookings Papers on Economic Activity, 0(2): 219-70.

Edwards, Sebastian (2002): “Does the Current Account Matter?”, in Preventing Currency Crises in Emerging Markets, Sebastian Edwards and Jeffrey A. Frankel (editors), The University of Chicago Press.

Edwards, Sebastian (2004), “Thirty Years of Current Account Imbalances, Current Account Reversals, and Sudden Stops," IMF Staff Papers, (Forthcoming).

Edwards, Sebastian and Eduardo Levy-Yeyati (2003). "Flexible Exchange Rates as Shock Absorbers," National Bureau of Economic Research Working Paper 9867

Frenkel, Jacob A. and Assaf Razin (1987): Fiscal policies and the World Economy: An Intertemporal Approach. MIT Press.

Milesi-Ferretti, Gian Maria and Assaf Razin. (2000), “Current Account Reversals and Curreency Crises: Empirical Regularities” in P. Krugman (Ed), Currency Crises, U. of Chicago Press.

Quinn, Dennis P. (2003)"Capital Account Liberalization and Financial Globalization, 1890-1999: A Synoptic View”International Journal of Finance and Economics, 8,3: $189-2004$

Stiglitz, Joseph E. (2002), Globalization and its Discontent, W.W. Norton \& Co. 
Table 1

Current Account Reversals, Openness and Growth Treatment Effects Model - Two Steps Estimates

\begin{tabular}{|c|c|c|c|c|}
\hline Variable & (1.1) & (1.2) & $(1.3)$ & (1.4) \\
\hline & \multicolumn{4}{|c|}{ Panel $A$} \\
\hline Growth gap & $\begin{array}{c}0.843 * * \\
(33.1)\end{array}$ & $\begin{array}{c}0.84 \overline{3 * *} \\
(33.1)\end{array}$ & $\begin{array}{c}0.840 * * \\
(32.8)\end{array}$ & $\begin{array}{c}0.834 * * \\
(33.1)\end{array}$ \\
\hline Change in terms of trade & $\begin{array}{c}0.062^{* *} \\
(8.51)\end{array}$ & $\begin{array}{c}0.061^{* *} \\
(8.46)\end{array}$ & $\begin{array}{c}0.061 * * \\
(8.45)\end{array}$ & $\begin{array}{c}0.066^{* *} \\
(8.51)\end{array}$ \\
\hline Reversal & $\begin{array}{l}-6.025 \\
(5.66)\end{array}$ & $\begin{array}{l}-5.087 \\
(3.86)\end{array}$ & $\begin{array}{c}-2.710^{* *} \\
(2.32)\end{array}$ & $\begin{array}{l}-5.722 \\
(6.64)\end{array}$ \\
\hline Reversal*Trade Openness & $\begin{array}{c}0.032^{* *} \\
(3.66)\end{array}$ & $\begin{array}{c}0.034 * * \\
(3.78)\end{array}$ & & $\begin{array}{c}0.023 * * \\
(3.08)\end{array}$ \\
\hline \multirow[t]{2}{*}{ Reversal*Financial Openness } & & $\begin{array}{l}-0.024 \\
(1.21)\end{array}$ & $\begin{array}{l}-0.014 \\
(0.74)\end{array}$ & \\
\hline & \multicolumn{4}{|c|}{ Panel B } \\
\hline Current account deficit to GDP (-1) & $\begin{array}{c}0.114^{* *} \\
(9.82)\end{array}$ & $\begin{array}{c}0.11 \overline{4 * *} \\
(9.82)\end{array}$ & $\begin{array}{c}0.114 * * \\
(9.82)\end{array}$ & $\begin{array}{c}0.122 * * \\
(10.78)\end{array}$ \\
\hline External debt to GDP (-1) & $\begin{array}{c}0.004^{* *} \\
(2.30)\end{array}$ & $\begin{array}{c}0.004^{* *} \\
(2.30)\end{array}$ & $\begin{array}{c}0.004 * * \\
(2.30)\end{array}$ & \\
\hline Net international reserves to GDP (-1) & $\begin{array}{c}-0.148^{*} \\
(1.78)\end{array}$ & $\begin{array}{c}-0.148^{*} \\
(1.76)\end{array}$ & $\begin{array}{c}-0.148^{*} \\
(1.76)\end{array}$ & $\begin{array}{c}-0.188^{*} \\
(2.38)\end{array}$ \\
\hline Short term ext. debt to external debt (-1) & $\begin{array}{l}0.001 \\
(0.42)\end{array}$ & $\begin{array}{l}0.001 \\
(0.42)\end{array}$ & $\begin{array}{l}0.001 \\
(0.42)\end{array}$ & \\
\hline Incidence of reversals in region & $\begin{array}{c}1.522^{* *} \\
(2.50)\end{array}$ & $\begin{array}{l}1.524 \\
(2.50)\end{array}$ & $\begin{array}{l}1.524 \\
(2.50)\end{array}$ & $\begin{array}{c}1.556^{* *} \\
(2.70)\end{array}$ \\
\hline Domestic credit growth $(-1)$ & $\begin{array}{l}0.002 \\
(1.32)\end{array}$ & $\begin{array}{l}0.002 \\
(1.32)\end{array}$ & $\begin{array}{l}0.002 \\
(1.32)\end{array}$ & $\begin{array}{c}0.002 * \\
(1.78)\end{array}$ \\
\hline Log initial GDP per capita & $\begin{array}{c}-1.743 * * \\
(7.51)\end{array}$ & $\begin{array}{c}-1.743^{* *} \\
(7.51)\end{array}$ & $\begin{array}{c}-1.743^{* *} \\
(7.51)\end{array}$ & $\begin{array}{c}-0.845^{* *} \\
(3.71)\end{array}$ \\
\hline Financial Openness (-1) & $\begin{array}{l}-0.007 \\
(1.54)\end{array}$ & $\begin{array}{l}-0.007 \\
(1.55)\end{array}$ & $\begin{array}{l}-0.007 \\
(1.55)\end{array}$ & $\begin{array}{c}-0.009 * * \\
(2.09)\end{array}$ \\
\hline Hazard lambda & $\begin{array}{c}1.192 * * \\
(2.49)\end{array}$ & $\begin{array}{c}1.232 * * \\
(2.57)\end{array}$ & $\begin{array}{c}1.082 * * \\
(2.25)\end{array}$ & $\begin{array}{c}1.314 * * \\
(3.23)\end{array}$ \\
\hline rho & 0.284 & 0.347 & 0.257 & 0.346 \\
\hline sigma & 4.611 & 4.606 & 4.208 & 3.804 \\
\hline Wald chi2 & $1,634.1$ & $1,174.2$ & $1,221.9$ & $1,916.9$ \\
\hline Observations & 1,176 & 1,174 & 1,174 & 1,561 \\
\hline
\end{tabular}

Absolute value of z statistics in parentheses; (-1) denotes a one-period lagged variable; Countryspecific and year dummies are included as discussed in text, but are not reported.

*Significant at $10 \%$;* significant at $5 \%$. 


\section{ENDNOTES}

*Anderson Graduate School of Management, University of California, Los Angeles. 110 Westwood Plaza, Los Angeles, CA. 90095. I thank Roberto Alvarez for his assistance.

${ }^{1}$ An analysis in terms of sudden stops, rather than reversals, yields similar conclusions. 